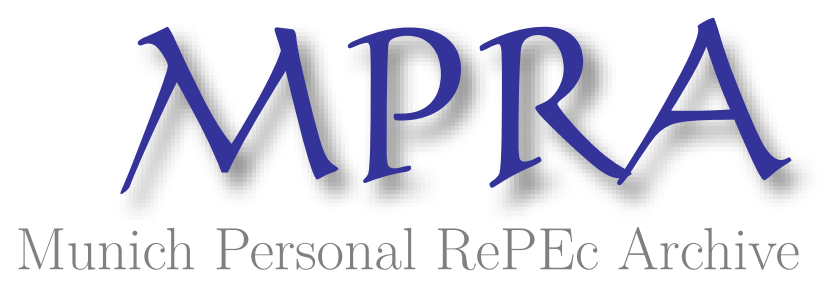

The Myths and Facts of Patent Troll and Excessive Payment: Have Non-Practicing Entities (NPEs) Been Overcompensated? - A Commentary

Blogg, Jonathan

April 2020

Online at https://mpra.ub.uni-muenchen.de/100069/

MPRA Paper No. 100069, posted 15 May 2020 05:11 UTC 


\section{The Myths and Facts of Patent Troll and Excessive Payment: Have Non-Practicing Entities (NPEs) Been Overcompensated?- A Commentary}

Jonathan S. Blogg, prepared in my personal capacity. For further queries email: jonathan.s.blogg@protonmail.com

\section{Contents}

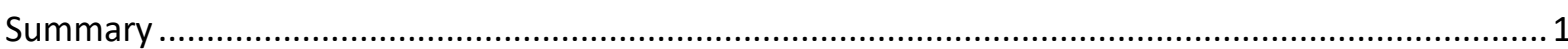

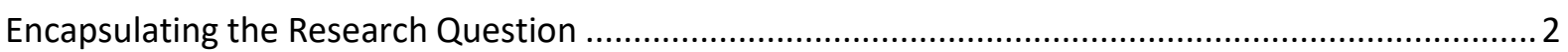

There is a lack of adequate definitions in the document .................................................................. 4

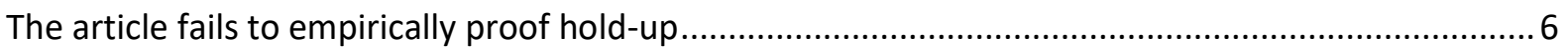

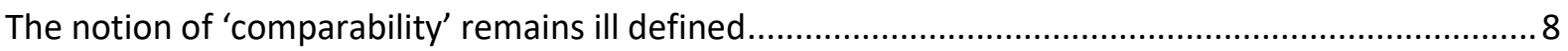

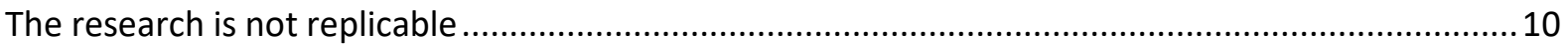

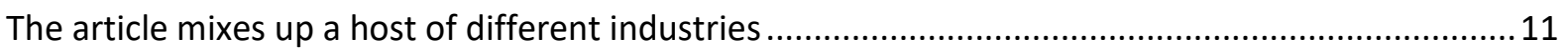

The research lacks adequate references to the academic literature ................................................. 12

The article suffers from multiple statistical and data shortcomings ................................................. 15

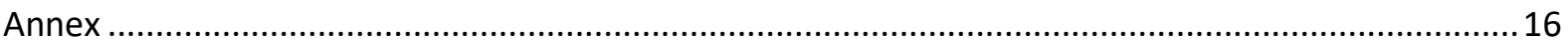

\section{Summary}

The much-cited article 'the Myths and Facts of Patent Troll and Excessive Payment: Have Non-Practicing Entities (NPEs) Been Overcompensated ${ }^{1}$, by Jack J. Lu is fundamentally flawed and based on data which cannot be retrieved. The key error results from poorly defined samples, selected to substantiate the statement that hold-up does not exist and that NonPracticing Entities are not overcompensated. Even if the article had succeeded in adequately selecting the samples subject to the analysis, the document would still fall short of determining what constitutes a comparable licensing agreement. Also, the findings cannot be verified as the article does not disclose the underlying data that leads to the conclusion that NPEs are not overpaid. Hence, the paper falls short of meeting three fundamental requirements of empirical research. There is no adequate selection of the two samples that are compared (the NPE sample and a vaguely defined sample of 'other companies'), there is also no adequate selection of comparable rates and last but not least, the data cannot be retrieved. Other than that, the

\footnotetext{
${ }^{1} \mathrm{Lu}$, J. J. (2012). The myths and facts of patent troll and excessive payment: have nonpracticing entities (NPEs) been overcompensated? Business Economics, 47, p.234. Title of the article

1 ibid, p. 245
} 
research paper suffers from the application of concepts which are not defined and lacks adequate references to the academic literature. These aspects taken together mean that it is not possible to draw any sorts of conclusions on the grounds of the analysis presented and render the article obsolete.

\section{Encapsulating the Research Question}

This article sets out to offer empirical proof that hold up is a myth and that an NPE, or "patent troll ${ }^{2}$, as called in the paper, is not overcompensated. In fact, the paper suggests that NPEs may be undercompensated. ${ }^{3}$

The article needs to be understood within the context of the wider political debate on the polemically called 'patent troll' phenomenon. The concept of using patents for the sole purpose of licensing them to third parties has been subject to hefty criticism. ${ }^{4}$ Arguments put forward for example have been that the role of the patent system is not to merely seek to extract funds from operating companies, but to provide a genuine incentive to invest in inventions. ${ }^{5}$ Such inventions are ideally in use in products and services and serve in one way or the other humanity.

An NPE to the contrary has as its business goal to obtain licensing income from third parties who use such inventions in products and services. Because an NPE does not produce anything, it cannot be counter sued for patent infringement. This, so the argument, can 'disarm' operating

\footnotetext{
${ }^{2} \mathrm{Lu}$, J. J. (2012). The myths and facts of patent troll and excessive payment: have nonpracticing entities (NPEs) been overcompensated? Business Economics, 47, p.234. Title of the article 3 ibid, p. 245

${ }^{4}$ Luman III, J. F., \& Dodson, C. L. (2006). No longer a myth, the emergence of the patent troll: stifling innovation, increasing litigation, and extorting billions. Intellectual Property \& Technology Law Journal, 18(5), 12-16, Helmers, C., Love, B., \& McDonagh, L. (2013). Is there a patent troll problem in the UK. Fordham Intell. Prop. Media \& Ent. LJ, 24, 509, Coursey, C. C. (2009). Battling the patent troll: tips for defending patent infringement claims by non-manufacturing patentees. Am. $J$. Trial Advoc., 33, 237.

${ }^{5}$ Heinecke, G. (2015). Pay the Troll Toll: The Patent Troll Model Is Fundamentally at Odds with the Patent System's Goals of Innovation and Competition. Fordham L. Rev., 84, 1153.
} 
companies. They may not be able to apply some of the litigation tactics that they would otherwise employ to counter a licensing request. ${ }^{6}$

The article reduces the complexity of the policy issues at stake to the simple question if NPEs are able to get higher royalty rates than other market participants. ${ }^{7}$ The question the document is eager to find empirical proof for is whether a NPEs are able to obtain supra normal royalty rates in damages, settlements, or royalties. ${ }^{8}$

The possibility that some operating companies can also act in an NPE type fashion is ignored in the text..$^{9}$ A company may for example operate in a different technology space as it licenses to and can hence also not be counter sued for that reason. The article does also not address the question whether NPEs are more easily able to extract royalty rates from third parties or if they can do so in a more cost-effective manner, which would be a highly interesting research question.

The author further more seeks to establish the argument that NPEs are over compensated by making use of the 'hold-up' terminology. ${ }^{10}$ Hold-up by background refers to a Wiliamson's transaction costs economics argument. ${ }^{11}$ Essentially, so the concept, an operating company has made important investments on the basis of a certain patented technology. If confronted with a licensing request, it either has the choice to comply with this licensing request or to write off its investments as sunk costs. This can mean that a licensing rate is reflective of the asymmetric

\footnotetext{
${ }^{6}$ Cooper, L. (2014). Patent Trolls and Other Bad Guys. Journal of Information Ethics, 23(2), 57.

${ }^{7} \mathrm{Lu}$, J. J. (2012). The myths and facts of patent troll and excessive payment: have nonpracticing entities (NPEs) been overcompensated? Business Economics, 47, p.235

${ }^{8}$ ibid, p. 235

${ }^{9}$ McMahon, T. P., Akerley, S. J., \& Bu, J. H. (2006). Who Is a Troll: Not a Simple Answer. In Sedona Conf. J. (Vol. 7, p. 159).

${ }^{10} \mathrm{Lu}$, J. J. (2012). The myths and facts of patent troll and excessive payment: have nonpracticing entities (NPEs) been overcompensated? Business Economics, 47, p.236, 237

${ }^{11}$ See for example. Shapiro, C. (2010). Injunctions, hold-up, and patent royalties. American Law and Economics Review, 12(2), 280-318 or Koss, P. A., \& Eaton, B. C. (1997). Co-specific investments, hold-up and self-enforcing contracts. Journal of Economic Behavior \& Organization, 32(3), 457-470.
} 
power relationship that prevails between the licensor and the licensee. By consequence, the licensee may be overpaying for a license. This argument forms an important part of the debate on standard essential patents, which the article makes no mention of.

Such a situation can be pronounced if the patent reads on a minor technological feature. This issue is ignored in the paper. It would for example be interesting to learn if patents that read on a minor feature of a technology obtain the same licensing rate as patents that protect core features.

\section{There is a lack of adequate definitions in the document}

In order to determine whether NPEs have been overcompensated or not, the article looks at the rates that one sample of companies received, which are called 'NPEs' and compares these rates with a sample, which are called 'other companies.' The article makes no statement what these rates are for, what the subject of the license is, how many patents the licensing agreement encompassed or if there are any other aspects in the licensing contract which would be worthwhile reflecting.

Furthermore, the article would need to provide core definitions of what is meant by the term 'overcompensated' ${ }^{12}$ or the term 'operating company. ${ }^{13}$ Who is qualified as 'other licensors'

\footnotetext{
${ }^{12}$ The term overcompensated is defined as 'higher payments than what the intrinsic value of the patent is.' Lu, p. 236 But what then is the intrinsic value of the patent? P. 246 contains a discussion of the 'value matrix puzzle' but it is not made clear if this debate defines the so-called 'intrinsic value' of the patent. On page 236 he argues that 'In other words, the patent holder commands a premium above the benchmark royalty by demanding a share of the saved redesign cost and/or a share of the infringer's profit during the redesign period. Whether this is the definition remains unclear in the paper.

${ }^{13}$ On p.240 I can only see what an operating company is not. It is not a university, research institute, federal laboratory or an individual. However, such a rough description provided with no further justification is not enough to define the term 'operating company' and help understand why it should obtain fundamentally different licensing rates from a NPE.
} 
remains unclear and is not further established in text. ${ }^{14}$ Throughout the article one is unable to find such a discussion as I show in the table below. ${ }^{15}$

Table 1: Key terms that would require a clear definition and the article's inadequate reflection of these definitions

\begin{abstract}
NPE
there is no adequate working definition for his empirical model. One can find a brief discussion of the term, but it is unclear what definition is used for the empirical model and if the statement made informs the model or not. 16
\end{abstract}

Intrinsic Value

There is no definition of the term intrinsic value. The statement is instrumental in informing hold-up; hence it would be important to identify a definition that informs the empirical model, but this cannot be found in the paper. ...patent trolls are a subset of NPEs, and that some business models are perceived to be more troll-like than others. The noninnovating NPEs (NINPEs), with revenue mainly from settlements and damage awards are the most troll-like. Alternatively, the narrowest definition of troll is an NPE that uses weak patents to hold up practicing companies or to file multiple suits that result in settlements because the practicing ${ }^{17}$ The argument that NPEs may hold up practicing companies and demand higher payments than the intrinsic value of a patent is intuitively appealing. ${ }^{18}$

The article contains a discussion of the 'value matrix puzzle' but it is not made clear if this debate defines the so-called 'intrinsic value' of the patent. ${ }^{19}$ It is furthermore argued that 'In other words, the patent holder commands a premium above the benchmark royalty by demanding a share of the saved redesign cost and/or a share of the infringer's profit during the redesign period. ${ }^{206}$

Whether this is the definition remains unclear in the paper.

\footnotetext{
14 'This study takes an alternative approach, the market-comparable approach, which compares the royalties earned by NPE licensors with those earned by other licensors.' Lu P. 240 Furthermore on p.240 Lu defines 'other licensors' as 'practicing companies as licensors and exclude transactions with licensors as universities, research institutions, federal laboratories, and individuals.' Also here it is unclear what is meant by the notion of a practicing company.

${ }^{15}$ I take note that in the concluding section the author offers a discussion of the term 'value matrix'. p.246 However, this discussion does not inform his model.

${ }^{16}$ Lu, p. 235

${ }^{17}$ Lu, p. 235

${ }^{18}$ Lu, p. 236

${ }^{19}$ Lu, p. 246

${ }^{20}$ Lu, p. 236
} 


\begin{tabular}{|l|l|}
\hline $\begin{array}{l}\text { 'Other Licensors' } \\
\text { This term informs the empirical model, but } \\
\text { one does not receive a clear definition of } \\
\text { what is meant by this term. One only reads } \\
\text { about 'other licensors' and that such firms } \\
\text { are not 'universities, research institutions, } \\
\text { federal laboratories, and individuals.' }\end{array}$ & $\begin{array}{l}\text { 'Other licensors' are described as } \\
\text { exclude transactions with licensors as } \\
\text { universities, research institutions, federal } \\
\text { laboratories, and individuals.' }\end{array}$ \\
$\begin{array}{l}\text { Also here it is unclear what is meant by the } \\
\text { notion of a practicing company. }\end{array}$ \\
\hline $\begin{array}{l}\text { Market Comparable Approach } \\
\text { This term is inadequately defined in the } \\
\text { paper. It is only explained with reference to a } \\
\text { comparison between 'NPEs' and 'other } \\
\text { licensors.' That is, it is briefly mentioned } \\
\text { with respect to two other terms which are } \\
\text { also not adequately defined. }\end{array}$ & $\begin{array}{l}\text { This study takes an alternative approach, the } \\
\text { market-comparable approach, which } \\
\text { licensors the royalties earned by NPE } \\
\text { licensors. }\end{array}$ \\
\hline $\begin{array}{l}\text { Over Compensation those earned by other } \\
\text { The term is defined with reference to the }\end{array}$ \\
$\begin{array}{l}\text { 'intrinsic value'. Since the term 'intrinsic } \\
\text { value is not properly defined it is also not } \\
\text { possible to understand what is meant by the } \\
\text { term overcompensation. }\end{array}$ & $\begin{array}{l}\text { The term overcompensated is defined as } \\
\text { 'higher payments than what the intrinsic } \\
\text { value of the patent is.' }\end{array}$ \\
$\begin{array}{l}\text { But what then is the intrinsic value of the } \\
\text { patent? }\end{array}$
\end{tabular}

Apart from the many other substantial flaws that this research piece suffers from, this lack of definitions is fatal. If one is not even able to understand what phenomenon one is actually seeking to decipher, how can one assess its economic effect?

\section{The article fails to empirically proof hold-up}

In spite of a lengthy discussion, the empirical model does not succeed in assessing whether hold-up exists or not. Instead, the article undertakes an assessment on what is called the 'market based comparable rate. ${ }^{24}$ There is no discussion of this method in the paper and there is also no explanation given why this method is selected over another valuation approach. There is also no discussion as to what insight can be gained from this valuation approach, nor why the

\footnotetext{
${ }^{21}$ Lu, p. 240

22 Lu, p. 240

${ }^{23}$ Lu, p. 236

24 Lu, J. J. (2012). The myths and facts of patent troll and excessive payment: have nonpracticing entities (NPEs) been overcompensated? Business Economics, 47, p. 239, 240
} 
comparable licenses approach is fit to address the research question. Hence, the sole factor that informs the empirical analysis is the notion of a 'benchmark.' 25

The data used is unverifiable. In fact, neither ktMine ${ }^{26}$ nor Royalty Source ${ }^{27}$ allow to publicly disclose information obtained from their database. This is why these data sources fail to provide the necessary baseline to verify this model. ${ }^{28}$

Even if one leaves all these shortcomings aside, the way the comparable approach is undertaken is inadequate. It is unclear what constitutes a comparable licensing contract in this model. The paper provides a range of search criteria. ${ }^{29}$ These search criteria are used to instruct staff from ktMine and RoyaltySource to undertake a search for licensing agreements in their respective databases. However, these are just practical instructions. For example, only licensing

${ }^{25}$ P. 239 and 240 he describes the benchmark as the 'market based comparable' rate. But what this means is not further established, nor how one can come to this conclusion. P. 236 furthermore describes that 'the patent holder commands a premium above the benchmark royalty by demanding a share of the saved redesign cost and/or a share of the infringer's profit during the redesign period.' ${ }^{26}$ See ktMine Terms and Conditions of use for ktMine. Available at http://rrf.ktmine.com/TermsOfService.aspx (last checked 1.4.2020)

${ }^{27}$ RoyaltySource Data Use Agreement. Available at https://royaltysource.com/data_use_agreement.html (last checked 1.4.2020)

${ }^{28}$ The author could only go and try to find the original sources through the sites that ktMine and RoyaltySource seek to aggregate, such as the website of the SEC (Securities Exchange Commission), but this would be a very time-consuming exercise.

${ }^{29} \mathrm{Lu}, \mathrm{J} . \mathrm{J}$. (2012). The myths and facts of patent troll and excessive payment: have nonpracticing entities (NPEs) been overcompensated? Business Economics, 47, p. 240

The following search criteria are used to search for the licensing transactions:

(a) Include only transactions with fixed or flat running royalty rates expressed as percentages of sales.

(b) Exclude licensing transactions as part of settling litigation or by court orders to insure that conclusions are based on market forces.

(c) Exclude licensing transactions between NPEs or their subsidiaries. The searches yielded 46 transactions with fixed running royalty rates as percentages of sales, with NPEs as licensors. The second step is to generate comparable transactions in which licensors are not NPEs, based on the criteria listed above and the following:

(d) Match each of the 46 transactions by industry and technology field.

(e) Include only the transactions with practicing companies as licensors and exclude transactions with licensors as universities, research institutions, federal laboratories, and individuals.6 For each of the 46 NPE transactions, two comparable transactions are compiled based on criteria (a), (b), (d), and (e), yielding a list of 92 comparable transactions. As a result, a total of 138 license agreements are collected as a result of reviewing 1,100 license agreement summaries and 315 license agreements. 
agreements are selected that contain a running royalty rate and are based on net sales. This alone constitutes a selection bias. One can very well select comparable licensing rates which are not based on net sales and are not hinged on a running royalty rate. However, one needs to then make the effort to adjust those rates so to express those rates in a similar fashion. Why the research design does not include this effort is not understandable. Equally important to note is that these practical instructions are not embedded in any legal or economic context whatsoever.

\section{The notion of 'comparability' remains ill defined}

Data provided by ktMine and RoyaltySource shows a high level of heterogeneity. Who the licensor and licensee are, their market size, geographical scope, their market power or sales volume can all influence the dynamics of the licensing negotiation and by consequence the licensing rate. Equally, the effective year and the duration of the licensing contract influence the value of a licensing transaction. Other factors that can have an influence on the worth of a licensing contract are the royalty base, the subject of the license, the size and strength of the patent portfolio, whether the license only covers patents or other intangibles, if it is a cross license or if there are additional payments made. The table below offers an overview of the type of data structure that one may expect from such databases.

Table 2: Typical Categories one may expect in Databases for Comparable Licenses

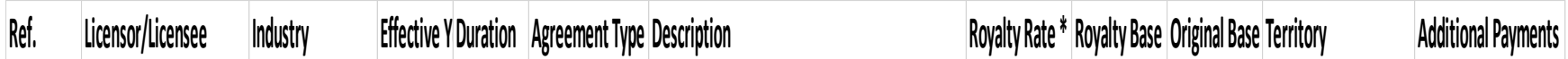

Chien discusses these in his article and shows that 'the majority of material software licenses reported by public companies to the SEC from 2000-2015 ( $\mathrm{N}=245)$, which are nonrepresentative of licenses in general, to support true technology transfer. The research was 
based on reading through hundreds of licensing contracts. ${ }^{30}$ This insight is informative as the author's research team has actually read the licensing contracts and offered a comprehensive insight into the agreements as a whole. I am unable to see that for the purpose of this research the entire licensing agreements were read and analysed. ${ }^{31}$

One cannot correct the substantial flaw of having failed to adequately encapsulate the notion of a benchmark in the context of this research piece. This, jointly with the unverifiable data presented are substantial and fundamentally irreparable errors of this document and they make the discussion presented in this report useless.

Even if the articles based its claim on one single valuation method, it would have been necessary to substantiate the notion of comparability. In a U.S. context the article could have made use of the Georgia Pacific Criteria, ${ }^{32}$ which are annexed to this comment.

The Georgia Pacific Criteria stipulate that factors such as the rate paid by the licensee for similar patents need to be considered, that one needs to understand the commercial relationship between the licensor and the licensee, understand the duration of the patent and term of the license. They also ask, among other things that one needs to understand the profits of the product made under the patent, its commercial success and current popularity and that one needs to get a grasp of the performance of the patented technology over older technological solutions or next best alternatives. One should further seek to understand the extent to which the infringer has made use of the invention; and any evidence probative of the value of that use. Georgia Pacific Criteria 12 also requires that one determines the portion or of the selling price that may be customary in the particular business or in comparable businesses to allow for the use of the invention or analogous inventions. Criteria 13 again asks that one should

\footnotetext{
${ }^{30}$ Chien, C. V. (2017). The Market for Software Innovation Through the Lens of Patent Licenses and Sales. Berkeley Tech. LJ (2017), 31.

${ }^{31} \mathrm{Lu}$ only identifies on p. 240 the criteria already discussed above.

${ }^{32}$ Georgia-Pacific Corp. v. United States Plywood Corp., 318 F.Supp. 1116, 1120, 1121.
} 
determine the portion of the realizable profit that should be credited to the invention as distinguished from non-patented elements, the manufacturing process, business risks, or significant features of improvements added by the infringer. What is cited here is not exhaustive.

Had the article taken the Georgia Pacific framework under consideration, it would have forced the article to assess the commercial dynamics that prevail between the licensor or licensee. This in itself is a substantial effort as it requires to understand the dynamics that prevailed at the time the license was concluded. Also, it is important to assess the contribution the patent had to the infringer's business. What role did the patent play in the infringer's company? Was the patented technology crucial to the infringer's corporate success? Was it a patent that read on a standard and hence subject to the RAND (reasonable and non-discriminatory) agreement? What were the technical features of the patent? Was it a portfolio of patents that was licensed or just a single patent?

Even if the article had opted to work outside the Georgia Pacific Framework, it would have still been necessary to come to grips with the notion of comparability. It would have been necessary to study in depth the subject matter of the license, the patents that are subject to the license, the age of the license or other criteria that help establish the notion of comparability.

The paper offers no insight on any of these crucial questions. I understand that this is a massive undertaking, but it would be instrumental to make such assessments so to gain an insight into the comparability of the licensing contracts under analysis.

\section{The research is not replicable}

The highly in transparent sample article presents is not tested for such criteria. This is a critical and equally fatal error. The few practical instructions that were given to the search team of ktMine and RoyaltySource are not enough to provide substantiated insights into this matter. 
Jurisprudence around the world has shown that the choice of the comparable licensing contract in a benchmark approach is a crucial element of a royalty rate determination. The types of licensing rates that Courts allowed and/or rejected have also been instrumental in shaping substantial aspects of the law and reasoning on what is 'comparable.'

When comparable licensing rates are being used in judicial proceedings, Courts tend to usually permit only a handful of licensing contracts. Often, there are not more than one or two licensing contracts that a Court admits as a comparable agreement. However, this article claims to have been able to cover a sample size of 138 licensing agreements. ${ }^{33}$ In my opinion, this is only possible because the criteria for comparability are relaxed and the Georgia Pacific criteria are ignored.

\section{The article mixes up a host of different industries}

The article also mixes up a host of different industries in the empirical analysis. In particular, it looks at sectors as diverse as the biological and pharmaceutical industry, the semiconductor sector and the telecommunication sector. There is also a completely undefined sector called 'others. ${ }^{34}$ All of these sectors have different market dynamics and the role that IP can play there is different.

In the pharmaceutical sector for example, patents are often used to protect a single product (i.e. a medication) and much of the debate centres around the access of patented medication and the role of generic companies. In the telecommunications sector again, the role IP can assume is quite different. Here much of the debate is about patents and network access. Historically, NPEs have found this area to be a more appealing playing ground than the pharmaceutical sector. The reason is simple. The patents that protect the medication are usually owned by a

\footnotetext{
${ }^{33}$ Lu, p. 240 Table 3

${ }^{34}$ Lu, p.240 Table 3
} 
pharmaceutical company itself and it is not customary to outsource such patents to a NPE, so it can obtain royalties from infringers. Rather, the pharmaceutical industry is keen to obtain an injunction. Hence, involving a NPE makes little sense in this context.

I am just citing here some examples. Certainly, more could be said about the market and IP dynamics in these various sectors. However, in this paper I do not see any debate of these various sectors and it is also not clear why these specific sectors are selected and not other ones. Such a debate would however be crucially important, so to inform the empirical model.

\section{The research lacks adequate references to the academic literature}

Other issues with this paper pertain to the overall negligence in the way the document is referenced and the way the NTP, Inc v RIM Ltd case is discussed. The NTP, Inc v RIM Ltd case is cited, but the reason why the public at large criticised the case remains not addressed. In particular, it is cautiously omitted to discuss the reason for the public outrage. ${ }^{35}$

In the introductory sections for example the article seeks to establish various strings in the academic literature, but fails to offer any reference whatsoever that would actually allow to understand who and what is actually meant with this string of academic literature. ${ }^{36}$

\footnotetext{
${ }^{35}$ Ibid, p. 234

${ }^{36} \mathrm{Lu}, \mathrm{p} .234$ - who is he citing here?
}

The NPE business model has also sparked hot debate among legal scholars and economists. Some believe that the business model is against the fundamental principles of patent law and that NPEs take advantage of loopholes in current patent law to file excessive and often baseless lawsuits against practicing companies. In their view, this has overburdened producers, stifled innovation, and clogged up the court system. However, other scholars argue that NPEs are generally premarket.

p. 235 - who is he citing here?

Alternatively, the narrowest definition of troll is an NPE that uses weak patents to hold up practicing companies or to file multiple suits that result in settlements because the practicing companies want to avoid the costs of litigation. 
Table 3: Statements made in Lu's paper, which lack a Reference

\begin{tabular}{|c|c|}
\hline $\begin{array}{l}\text { The NPE business model has also sparked } \\
\text { hot debates among legal scholars and } \\
\text { economists. Some believe that the business } \\
\text { model is against the fundamental principles } \\
\text { of patent law and that NPEs take advantage } \\
\text { of loopholes in current patent law to file } \\
\text { excessive and often baseless lawsuits } \\
\text { against practicing companies. In their view, } \\
\text { this has overburdened producers, stifled } \\
\text { innovation, and clogged up the court } \\
\text { system. }\end{array}$ & $\begin{array}{l}\text { Statement is not referenced. } \\
\text { Who are those legal scholars and } \\
\text { economists? } \\
\text { Why did they say that and in what context? }\end{array}$ \\
\hline $\begin{array}{l}\text { However, other scholars argue that } \\
\text { NPEs are generally promarket. NPEs can } \\
\text { compensate those innovators and } \\
\text { entrepreneurs who exit-voluntarily or } \\
\text { involuntarily-for their innovation and } \\
\text { entrepreneurship, thus helping to ensure that } \\
\text { the innovations are introduced into the } \\
\text { economy. }\end{array}$ & $\begin{array}{l}\text { Statement is not referenced. } \\
\text { Who are those other scholars? } \\
\text { Why did they say that and in what context? }\end{array}$ \\
\hline $\begin{array}{l}\text { Also, by acting as intermediaries in license } \\
\text { markets, NPEs increase market liquidity and } \\
\text { efficiency. } 39\end{array}$ & $\begin{array}{l}\text { Statement is not referenced. No evidence } \\
\text { offered to substantiate the argument. }\end{array}$ \\
\hline $\begin{array}{l}\text { The stakes in the debate over the impact of } \\
\text { NPEs is high for all players, especially in } \\
\text { light of current legislative efforts to reform } \\
\text { patent law. }\end{array}$ & $\begin{array}{l}\text { Statement is not referenced. } \\
\text { What legislative reform is being referred to } \\
\text { here? }\end{array}$ \\
\hline $\begin{array}{l}\text { Alternatively, the narrowest definition of } \\
\text { troll is an NPE that uses weak patents to } \\
\text { hold up practicing companies or to file } \\
\text { multiple suits that result in settlements } \\
\text { because the practicing companies want to } \\
\text { avoid the costs of } \\
\text { litigation. }\end{array}$ & $\begin{array}{l}\text { Statement is not referenced. } \\
\text { No evidence offered to substantiate the } \\
\text { argument }\end{array}$ \\
\hline $\begin{array}{l}\text { On the other hand, a significant pool of } \\
\text { literature argues that although holdup can be } \\
\text { adopted by both NPEs and practicing } \\
\text { companies as a tactic to obtain exorbitant } \\
\text { payments from targeted companies, the } \\
\text { expected rate of success and the magnitude } \\
\text { of overpayment are dependent on restrictive }\end{array}$ & $\begin{array}{l}\text { Statement is not referenced. } \\
\text { No evidence offered to substantiate the } \\
\text { argument. } \\
\text { Who stated this? } \\
\text { What were their findings? } \\
\text { Why are they restrictive and simplifications? }\end{array}$ \\
\hline
\end{tabular}

\footnotetext{
${ }^{37} \mathrm{Lu}$, J. J. (2012). The myths and facts of patent troll and excessive payment: have nonpracticing entities (NPEs) been overcompensated? Business Economics, 47, p.234

${ }^{38}$ Ibid, p. 234

${ }^{39}$ Ibid, p. 234

${ }^{40}$ Ibid, p. 235

${ }^{41}$ Ibid, p. 235
} 


\begin{tabular}{|c|c|}
\hline assumptions and simplifications. ${ }^{42}$ & \\
\hline $\begin{array}{l}\text { In other words, the outcomes of holdup } \\
\text { tactics are specific to the assumptions made } \\
\text { by the various models, and these } \\
\text { assumptions rarely hold in the real world of } \\
\text { licensing. }{ }^{3}\end{array}$ & $\begin{array}{l}\text { Statement is not referenced. } \\
\text { Why? What can be done to substantiate this } \\
\text { argument? There is no proof offered for this } \\
\text { statement. }\end{array}$ \\
\hline $\begin{array}{l}\text { In stark contrast to the literature in } \\
\text { theoretical } \\
\text { modelling and analytical study, empirical } \\
\text { research is scanty. }\end{array}$ & $\begin{array}{l}\text { Statement is not referenced. There is no } \\
\text { proof offered for this statement. }\end{array}$ \\
\hline $\begin{array}{l}\text { A few recent empirical studies offer } \\
\text { contradicting evidence, with some studies } \\
\text { affirming overcompensation and others } \\
\text { refuting it. }{ }^{45}\end{array}$ & $\begin{array}{l}\text { Statement is not referenced. } \\
\text { Who stated this? } \\
\text { What were their findings? }\end{array}$ \\
\hline $\begin{array}{l}\text { Furthermore, empirical research to date } \\
\text { concentrates largely on litigated patents and } \\
\text { patent damage awards. }{ }^{46}\end{array}$ & $\begin{array}{l}\text { Statement is not referenced. } \\
\text { Who stated this? } \\
\text { What were their findings? }\end{array}$ \\
\hline $\begin{array}{l}\text { This finding contradicts the argument } \\
\text { that NPEs are systematically } \\
\text { overcompensated, } \\
\text { at least based on evidence from the license } \\
\text { market. }{ }^{47}\end{array}$ & $\begin{array}{l}\text { Statement is not referenced. } \\
\text { Who stated this? } \\
\text { What were their findings? }\end{array}$ \\
\hline $\begin{array}{l}\text { The conclusion reached in this paper, } \\
\text { coupled } \\
\text { with other major findings from relevant } \\
\text { empirical studies about NPEs, patent } \\
\text { litigation, and damage awards... } 48\end{array}$ & $\begin{array}{l}\text { Statement is not referenced. } \\
\text { What are these major findings? }\end{array}$ \\
\hline $\begin{array}{l}\text { First of all, conventional economics of } \\
\text { industrial organization theory imply that } \\
\text { royalty rates charged by NPEs will be } \\
\text { higher because of pricing inefficiencies. }{ }^{49}\end{array}$ & $\begin{array}{l}\text { Statement is not referenced. } \\
\text { Which conventional economics? } \\
\text { Who says that? }\end{array}$ \\
\hline $\begin{array}{l}\text { While economists have long used such } \\
\text { metrics to measure the value of patents, }{ }^{50} \ldots\end{array}$ & $\begin{array}{l}\text { Statement is not referenced. } \\
\text { Which economists? } \\
\text { Who said that? }\end{array}$ \\
\hline
\end{tabular}

${ }^{42}$ Ibid, p. 235

${ }^{43}$ Ibid, p. 235

${ }^{44}$ Ibid, p. 235

${ }_{45}$ Ibid, p. 235

${ }^{46}$ Ibid, p. 235

${ }^{47}$ Ibid, p. 235

${ }^{48}$ Ibid, p. 235

${ }^{49}$ Ibid, p. 239

${ }^{50}$ Ibid, p. 246 
Certain passages of Lu's paper are written in a polemic manner, which reveal in my opinion the political motivation of the paper.

Table 4: Polemic Statements in the paper

\begin{tabular}{|c|c|}
\hline $\begin{array}{l}\text { Some NPEs assert their } \\
\text { patents against practicing } \\
\text { companies that have made } \\
\text { irreversible capital } \\
\text { investments in the patented } \\
\text { technology in order to } \\
\text { demand exorbitant royalties } \\
\text { or seek excessive } \\
\text { settlements and damage } \\
\text { awards-a practice } \\
\text { commonly referred to as } \\
\text { holdup or trolling. }\end{array}$ & $\begin{array}{l}\text { Comparing patent hold-up to } \\
\text { trolling comes across as } \\
\text { rather polemic. }\end{array}$ \\
\hline $\begin{array}{l}\text { Still, because NPEs do not } \\
\text { need operating freedom in } \\
\text { production and cannot be } \\
\text { countersued, they may } \\
\text { substantially increase holdup } \\
\text { risk and therefore can be } \\
\text { more dangerous.52 }\end{array}$ & $\begin{array}{l}\text { The term 'dangerous' comes } \\
\text { across as rather polemic. }\end{array}$ \\
\hline
\end{tabular}

\section{The article suffers from multiple statistical and data shortcomings}

Besides multiple statistical and data shortcomings, the article also suffers from severe problems regarding the applied methodology and the chosen research approach. The analysed licencing rates exhibit a strong degree of heterogeneity. Just accounting for a few licence variations, such as different industries, will not improve the deeper comparability issue. In other words, data limitations and the complexity of the licencing process of NPEs and practicing companies make it impossible to systematically analyse a potential overcompensation through the lens of a statistical model. Therefore, using a methodology based on an econometric framework such as the one used here will deliver unreliable results.

\footnotetext{
${ }^{51}$ Ibid, p. 234

${ }^{52}$ Ibid, p. 237
} 
One will need to accept that highly complex issues such as what impact NPEs have on the economy and society at large cannot be answered with a simple yes or no. Against this background, the only reasonable thing to do would be to retract the document.

\section{Annex}

\section{Georgia Pacific Criteria ${ }^{53}$}

1. The royalties received by the patentee for the licensing of the patent in suit, proving or tending to prove an established royalty.

2. The rates paid by the licensee for the use of other patents comparable to the patent in suit.

3. The nature and scope of the license, as exclusive or non-exclusive; or as restricted or nonrestricted in terms of territory or with respect to whom the manufactured product may be sold.

4. The licensor's established policy and marketing program to maintain his patent monopoly by not licensing others to use the invention or by granting licenses under special conditions designed to preserve that monopoly.

5. The commercial relationship between the licensor and licensee, such as, whether they are competitors in the same territory in the same line of business; or whether they are inventor and promoter.

6. The effect of selling the patented specialty in promoting sales of other products of the licensee; that existing value of the invention to the licensor as a generator of sales of his nonpatented items; and the extent of such derivative or convoyed sales.

7. The duration of the patent and the term of the license.

8. The established profitability of the product made under the patent, its commercial success; and its current popularity.

9. The utility and advantages of the patent property over the old modes or devices, if any, that had been used for working out similar results.

10. The nature of the patented invention; the character of the commercial embodiment of it as owned and produced by the licensor; and the benefits to those who have used the invention.

11. The extent to which the infringer has made use of the invention; and any evidence probative of the value of that use.

12. The portion of the profit or of the selling price that may be customary in the particular business or in comparable businesses to allow for the use of the invention or analogous inventions.

${ }^{53} 318$ F. Supp. 1116 (S.D.N.Y. 1970) at 1120 
13. The portion of the realizable profit that should be credited to the invention as distinguished from non-patented elements, the manufacturing process, business risks, or significant features or improvements added by the infringer.

14. The opinion testimony of qualified experts.

15. The amount that a licensor (such as the patentee) and a licensee (such as the infringer) would have agreed upon (at the time the infringement began) if both had been reasonably and voluntarily trying to reach an agreement; that is, the amount which a prudent licensee-- who desired, as a business proposition, to obtain a license to manufacture and sell a particular article embodying the patented invention-- would have been willing to pay as a royalty and yet be able to make a reasonable profit and which amount would have been acceptable by a prudent patentee who was willing to grant a license. 